Márcio Herescu Fleury

Matrícula 0411887

Monografia - Direito - PUC-Rio

Período 2010.1 

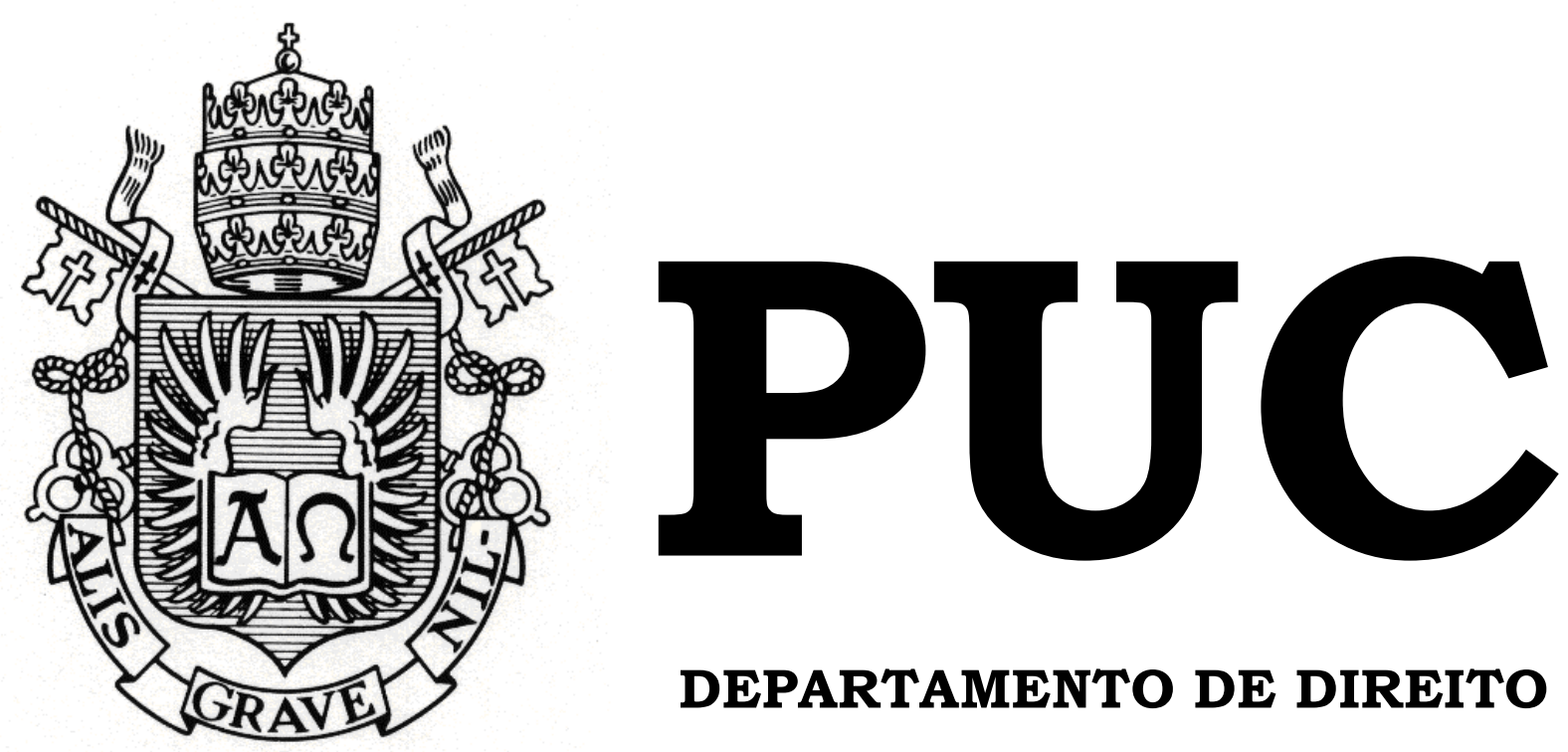

DEPARTAMENTO DE DIREITO

O SIMPLES NACIONAL E O ESTATUTO NACIONAL DA MICROEMPRESA E DA EMPRESA DE PEQUENO PORTE

por

MÁRCIO HERESCU FLEURY

ORIENTADOR: LAURO DA GAMA E SOUZA JÚNIOR 2010.1

PONTIFÍCIA UNIVERSIDADE CATÓLICA DO RIO DE JANEIRO RUA MARQUÊS DE SÃO VICENTE, 225 - CEP 22453-900 RIO DE JANEIRO - BRASIL 


\title{
O SIMPLES NACIONAL E O ESTATUTO NACIONAL DA MICROEMPRESA E DA EMPRESA DE PEQUENO PORTE
}

\author{
por \\ MÁRCIO HERESCU FLEURY
}

Monografia apresentada ao

Departamento de Direito da Pontificia Universidade Católica do Rio de Janeiro (PUC-Rio) como requisito parcial para a obtenção do título de Bacharel em Direito.

Orientador: LAURO DA GAMA E SOUZA JÚNIOR 


\section{Resumo}

O presente trabalho tem como objetivo resumir e explicar os fundamentos e os principais aspectos do Estatuto Nacional da Microempresa e da Empresa de Pequeno Porte, particularmente no que diz respeito ao regime simplificado de tributação por ele introduzido, o Simples Nacional, bem como expor alguns dos benefícios trazidos pela legislação.

A bibliografia sobre a matéria ainda é muito reduzida e, dada a abrangência e a originalidade do novo regime, muitos contribuintes, agentes públicos e até especialistas ainda têm dúvidas sobre o funcionamento do Simples Nacional e sobre os benefícios do novo Estatuto. Isto torna importante empreender estudos sobre as normas tendentes a simplificar as obrigações das empresas e seu alcance prático.

Para melhor expor o objeto deste trabalho, a monografia foi dividida em duas partes. A primeira apresenta os antecedentes históricos que levaram à edição do Estatuto, bem como os aspectos gerais do regime do Simples Nacional. A segunda analisa os aspectos que influenciam diretamente a situação dos contribuintes incluídos no regime e faz, a título de exemplo, uma rápida análise da situação das Micro e Pequenas Empresas no Município do Rio de Janeiro, bem como dos impactos resultantes na arrecadação municipal.

\section{PALAVRAS-CHAVE}

Micro e Pequenas Empresas - Tratamento Diferenciado - Simplificação 
$\begin{array}{ll}\text { PARTE I } & 7\end{array}$

Capítulo 1 - Origens e antecedentes históricos $\quad 7$

$\begin{array}{ll}1.1 \text { - As MPE e o Sistema Tributário Nacional } & 7\end{array}$

$\begin{array}{ll}1.2 \text { - As MPE na Constituição Federal } & 11\end{array}$

1.3 - Regimes anteriores ao Simples Nacional $\quad 15$

Capítulo 2 - Aspectos gerais do Simples Nacional 17

2.1 - Coordenação e regulamentação do sistema 17

2.2 - Tributos abrangidos pelo Simples Nacional 18

$\begin{array}{ll}2.3 \text { - O conceito de micro e pequena empresa } & 20\end{array}$

2.4 - Vedações ao ingresso no sistema $\quad 21$

$\begin{array}{ll}2.5 \text { - Requisitos para o ingresso no sistema } & 23\end{array}$

2.6 - Exclusão do sistema $\quad 24$

2.7 - Fiscalização e penalidades $\quad 25$

2.8 - Processo Judicial $\quad 27$

$\begin{array}{ll}\text { PARTE II } & 28\end{array}$

Capítulo 3 - Efeitos do novo regime para os contribuintes $\quad 28$

3.1 - Cálculo e recolhimento dos tributos $\quad 28$

3.2 - Obrigações acessórias $\quad 31$

3.3 - O microempreendedor individual

3.4 - Unificação dos cadastros e simplificação do registro 34

3.5 - Normas empresariais e benefícios extrafiscais 36

Capítulo 4 - As MPE no Município do Rio de Janeiro

4.1 - Antecedentes históricos na legislação municipal $\quad 39$

4.2 - Regulamentação do sistema no Município $\quad 41$

4.3 - Cadastro e fiscalização das empresas $\quad 42$

4.4 - Efeitos práticos na arrecadação municipal $\quad 44$

$\begin{array}{ll}\text { CONCLUSÃO } & 46\end{array}$

$\begin{array}{ll}\text { BIBLIOGRAFIA } & 49\end{array}$ 


\section{Lista de Abreviações}

ADCT - Ato das Disposições Constitucionais Transitórias

CGSN - Comitê Gestor do Simples Nacional

CNPJ - Cadastro Nacional da Pessoa Jurídica

CPP - Contribuição Previdenciária Patronal

CSLL - Contribuição Social sobre o Lucro Líquido

EC - Emenda Constitucional

EPP - Empresa(s) de Pequeno Porte

ICMS - Imposto sobre a Circulação de Mercadorias e Serviços

IPI - Imposto sobre Produtos Industrializados

ISS - Imposto sobre Serviços de Qualquer Natureza

LC - Lei Complementar

LG - Lei Geral das Micro e Pequenas Empresas

$\mathrm{ME}-\operatorname{Microempresa}(\mathrm{s})$

MEI - Microempreendedor Individual

MPE - Micro e Pequenas Empresas

MRJ - Município do Rio de Janeiro

ORTN - Obrigações Reajustáveis do Tesouro Nacional

RFB - Receita Federal do Brasil

SEBRAE - Serviço Brasileiro de Apoio às Micro e Pequenas Empresas 


\section{Introdução}

A edição do novo Estatuto Nacional da Microempresa e da Empresa de Pequeno Porte introduziu um novo paradigma no sistema de tributação adotado no Brasil, bem como no que diz respeito ao apoio ao empreendedorismo. Há muito que se fazia necessária uma legislação abrangente no que toca à situação das Micro e Pequenas Empresas (MPE), por sua importância na geração de empregos e no impulso ao crescimento da economia. Tal legislação, embora já prevista na Constituição de 1988, levou quinze anos para se completar.

A tributação das empresas ${ }^{1}$ costuma ser objeto de intensos debates no cenário político e na mídia nacional. Alguns defendem a manutenção e até o aumento da atual carga tributária, a fim de dotar o Estado de meios para cumprir seus fins essenciais. Outros preconizam a redução da carga como meio de aumentar a competitividade da economia nacional. O certo é que, independentemente da carga tributária propriamente dita, existe uma tendência, manifestada em leis editadas nas três esferas de poder, de reduzir o custo da tributação e do controle, isto é, o custo incorrido pelas empresas para cumprir suas obrigações tributárias e administrativas.

Conforme será descrito ao longo do trabalho, o Poder Público vem paulatinamente se convencendo de que é vantajoso tornar mais simples alguns mecanismos de controle, principalmente no que se refere às atividades das empresas de menor porte, pois muitas vezes o custo administrativo do controle não é compensado pela arrecadação obtida. Isso fica mais claro ainda quando se leva em conta o custo de oportunidade, ou

\footnotetext{
${ }^{1} \mathrm{O}$ conceito jurídico de empresa, tradicionalmente adotado no Direito Comercial, refere-se à atividade econômica organizada com fins lucrativos, exercida pelo empresário ou pela sociedade empresária. Neste trabalho, no entanto, a palavra "empresa" será sempre empregada na acepção corriqueiramente utilizada, ou seja, o empresário ou a sociedade empresária, com inscrição no CNPJ e tratamento tributário próprio de pessoa jurídica. As sociedades simples com finalidades econômicas também podem se encaixar neste último conceito de empresa. Porém, com algumas exceções, as atividades típicas dessa espécie de sociedade não podem ser incluídas no regime do Simples Nacional. Cabe lembrar ainda que o empresário individual não é pessoa jurídica propriamente dita, mas para fins tributários é tratado como tal.
} 
seja, a desvantagem de mobilizar recursos públicos para o controle das atividades dos contribuintes de menor porte.

Para além da análise da situação das MPE, pode-se dizer que o ponto central deste trabalho é a simplificação tributária e administrativa e suas vantagens, do ponto de vista tanto dos contribuintes quanto do Estado. Também se procura mostrar, ainda que de forma breve, a importância da simplificação para o funcionamento da economia como um todo, tendo em vista o ganho geral de eficiência e a aceleração das transações.

Vale ressaltar que não se pretende aqui fazer uma análise detalhada de todos os pontos da legislação relativa às MPE, tendo em vista a extensão e a complexidade das normas em questão. Apenas é traçado um panorama geral da legislação, procurando explicar seus fundamentos, seu alcance e seus efeitos concretos.

A bibliografia relacionada foi utilizada como referência e para estudo dos conceitos abordados no trabalho, não havendo no presente texto citações diretas dos autores pesquisados. Os dados referentes à arrecadação do Município do Rio de Janeiro, embora de caráter público, não estão agrupados em nenhuma publicação específica. Muitas das descrições, das análises e dos dados aqui apresentados decorrem da participação em palestras, de conversas diretas com profissionais e com pessoas ligadas à administração do sistema, bem como da prática profissional diária do autor do trabalho como agente da Administração Tributária municipal. 


\section{Parte I}

\section{Capítulo 1 - Origens e antecedentes históricos}

\section{1 - As MPE e o Sistema Tributário Nacional}

O sistema tributário brasileiro é considerado um dos mais complexos do mundo. Grande parte dessa complexidade deve-se à estrutura peculiar da federação brasileira, que se organiza em três níveis, cada um com autonomia para instituir e cobrar seus próprios tributos, conforme a distribuição de competências estabelecida pela Constituição Federal. Como exemplo de distinção em relação ao sistema federativo tripartite, temos a cobrança do Imposto sobre o Valor Adicionado, correspondente ao ICMS e ao ISS sobre as vendas e serviços direcionados ao consumidor final, conforme o regime adotado na Espanha: além de atender às normas gerais da Comunidade Européia, o imposto é de caráter nacional, tendo assim uma regulação única para todas as unidades territoriais, e possui apenas três alíquotas imponíveis, conforme a espécie de bem ou serviço tributado. Já no Brasil, as empresas tiveram que conviver, durante décadas, com diferentes regulamentações do ICMS e do ISS, muitas vezes conflitantes, adotadas pelos entes tributantes.

A necessidade de distribuir, entre os três níveis de governo, a competência para instituir e arrecadar tributos, bem como de atender às finalidades previstas na Constituição, faz com que sejam cobrados atualmente no país seis impostos federais, três impostos estaduais e três impostos municipais; três tipos de contribuição, instituídas pela União, subdivididas em dezenas de contribuições específicas; uma contribuição específica para a iluminação pública, de competência dos Municípios; e taxas específicas cobradas por cada ente tributante, conforme a atividade ou serviço ao qual dizem respeito. 
Um bom exemplo das dificuldades geradas pela distribuição de competências é o ICMS: as 27 unidades federativas que cobram esse imposto possuem 27 legislações diferentes, muitas vezes conflitantes entre si, o que às vezes torna difícil definir para qual entidade é devido o imposto e quais as regras aplicáveis a cada operação. Apesar de alguns convênios interestaduais, que uniformizaram o tratamento de questões específicas, ainda há muitas contradições no sistema, e as tentativas de se criar uma legislação unificada para o ICMS, até agora, foram infrutíferas. O ISS também apresenta alguns conflitos, nos casos em que o contribuinte presta serviços em um município diverso daquele em que está estabelecido. Nesses casos, não raro o contribuinte recolhe o imposto para um dos municípios, mas é autuado pela administração tributária de outro município, que entende que o imposto lhe é devido.

Para uma melhor compreensão da tributação das empresas, convém identificar os tributos que incidem diretamente sobre a atividade empresarial. Alguns dos tributos cobrados das empresas têm finalidade marcantemente regulatória: é o caso dos impostos sobre o comércio exterior e do IOF (Imposto sobre Operações Financeiras), todos de competência da União. Um exemplo disso é a recente instituição de uma alíquota de $2 \%$ de IOF sobre o capital externo, com o objetivo de conter a apreciação da moeda nacional em relação ao dólar.

Já os impostos sobre a propriedade e sobre a sua transmissão (IPTU, IPVA, ITBI, ITD, ITR), bem como as taxas fundiárias (cobradas dos proprietários de imóveis) e a contribuição para a iluminação pública, não têm relação direta com a atividade econômica. Isto ocorre porque a base de cálculo desses tributos não é proporcional ao aproveitamento econômico da propriedade. No caso dos impostos citados, a base da tributação é o valor da propriedade em si. No caso das taxas e da contribuição, o parâmetro para a cobrança é o custo dos serviços prestados pelo poder público. 
No que diz respeito à tributação das empresas, portanto, existem no país os seguintes tributos diretamente ligados à atividade empresarial:

Imposto sobre a Renda da Pessoa Jurídica - IRPJ;

Imposto sobre Produtos Industrializados - IPI;

Imposto sobre a Circulação de Mercadorias e Serviços - ICMS;

Imposto sobre Serviços de Qualquer Natureza - ISS;

Contribuição Social sobre o Lucro Líquido - CSLL;

Contribuição para o Financiamento da Seguridade Social - COFINS;

Contribuição para o PIS/Pasep;

Contribuição Patronal Previdenciária - CPP;

Contribuições para o Sistema "S" - pagas às entidades de serviço social e de formação profissional vinculadas à categoria econômica à qual pertence a empresa contribuinte.

Contribuição Sindical Patronal;

Taxas de polícia - cobradas em razão do exercício do poder de polícia pelos entes tributantes, conforme a atividade sujeita à sua incidência.

Além das já citadas acima, existe uma série de contribuições sociais instituídas pela União, que incidem sobre a atividade empresarial em situações específicas, como é o caso do salário-família, do salário-educação e outras. Vale lembrar ainda que a contribuição para o FGTS não tem natureza de tributo, conforme reiteradas decisões do STF e do STJ.

Independentemente da carga tributária propriamente dita, a amplitude e a complexidade do sistema tributário exigem das empresas um alto grau de organização, a fim de atender às exigências físcais e administrativas impostas pela legislação tributária de cada ente. Naturalmente, as MPE têm uma dificuldade muito maior de atender a tais exigências, uma vez que suas estruturas administrativas são de porte modesto. A própria organização minimamente necessária para atender a 
essas exigências, incluindo as obrigações acessórias, representa um custo que, para as MPE, constitui uma parcela significativa de sua receita. Essa dificuldade é um dos fatores responsáveis pelo elevado grau de informalidade e pela elevada mortalidade das MPE.

O próprio ato de abrir, registrar e pôr em funcionamento as empresas apresenta dificuldades consideráveis para as MPE, tendo em vista a burocracia envolvida. Sem os benefícios instituídos pelo novo Estatuto Nacional, as exigências federais, estaduais e municipais representam, em média, entre 70 e 80 documentos e ações. O tempo médio para abrir uma empresa é um reflexo dessa dificuldade: nos EUA, esse tempo é de 5 dias; no Irã, de 62 dias; já no Brasil, o tempo médio, até alguns anos atrás, chegava a 152 dias. Também é mais difícil o processo de encerramento de uma empresa no Brasil, já que, muitas vezes, é preciso proceder à baixa da inscrição nos três níveis de administração fazendária, além de consignar o encerramento no órgão de registro competente.

A necessidade de conferir tratamento diferenciado às MPE se torna ainda mais evidente quando se constata a sua importância na geração de empregos. Segundo a página do SEBRAE/SP, as MPE representam 98\% das empresas e $67 \%$ das ocupações, embora sua receita represente apenas $20 \%$ do PIB. Também é relevante o fato de que $62 \%$ das empresas paulistas não sobrevivem mais do que 5 anos em atividade, o que demonstra as dificuldades enfrentadas pelas MPE. Sobre a mortalidade das micro e pequenas empresas, cabe destacar que os registros empresariais oficiais não captam todas as variações, tendo em vista que muitas empresas deixam de funcionar, mas não fazem nenhuma comunicação aos órgãos oficiais de registro ou só a fazem muito tempo depois. Alguns estudos econômicos chegaram a constatar que $80 \%$ das microempresas brasileiras não conseguiam passar do primeiro ano de efetivo funcionamento. 


\section{2 - As MPE na Constituição Federal}

A Constituição de 1988 resultou da mobilização de diversas forças políticas e sociais, na esteira da redemocratização do país. O texto final foi produto de intensos debates, lutas e acordos entre as diferentes correntes políticas representadas na Assembléia Nacional Constituinte. De um lado, as forças mais à esquerda procuravam estabelecer um sistema de proteção social mais abrangente, próximo ao chamado socialismo europeu. De outro, as forças mais conservadoras procuravam minimizar a intervenção do Estado na economia e aumentar o espaço de atuação da iniciativa privada.

Desse embate resultou um texto que, a fim de estabelecer um consenso, definiu como fundamentos básicos da República os valores sociais do trabalho e da livre iniciativa. A Constituição estabelece uma ordem fundada na economia de mercado, mas que tem como finalidade última o bem-estar coletivo. Procurou-se estabelecer assim um equilíbrio entre os direitos fundamentais de primeira, segunda e terceira geração, que também podem ser denominados, respectivamente, direitos individuais, direitos sociais e direitos difusos.

Essa dupla ênfase revela-se também no artigo 170, que trata da ordem econômica constitucional, e define como princípios básicos, dentre outros, a propriedade privada e a livre concorrência, mas também a função social da propriedade e a busca do pleno emprego.

As ME e EPP possuem uma importância fundamental na ordem econômica nacional, justamente por serem capazes de abranger os seus dois fatores básicos: o trabalho humano e a livre iniciativa. Ao mesmo tempo em que constituem manifestações do espírito empreendedor, elas são elementos importantes na valorização do trabalho, inclusive porque, muitas vezes, o trabalho pessoal dos próprios empresários constitui um dos elementos essenciais da empresa. 
Por essa razão, o tratamento favorecido às MPE também foi incluído entre os princípios básicos estabelecidos no artigo 170:

"Art. 170. A ordem econômica, fundada na valorização do trabalho humano e na livre iniciativa, tem por fim assegurar a todos existência digna, conforme os ditames da justiça social, observados os seguintes princípios:

(...) IX - tratamento favorecido para as empresas de pequeno porte constituídas sob as leis brasileiras e que tenham sua sede e administração no País."

Já na redação original, a Constituição de 1988 previa o tratamento jurídico diferenciado, consistente na simplificação e na redução das obrigações das MPE, conforme detalhado no artigo 179:

“Art. 179. A União, os Estados, o Distrito Federal e os Municípios dispensarão às microempresas e às empresas de pequeno porte, assim definidas em lei, tratamento jurídico diferenciado, visando a incentivá-las pela simplificação de suas obrigações administrativas, tributárias, previdenciárias e creditícias, ou pela eliminação ou redução destas por meio de lei."

$\mathrm{O}$ benefício constitucional às MPE foi significativamente alargado pela EC 42/2003, que acrescentou a alínea "d" ao art. 146, III, prevendo que caberia à Lei Complementar definir o tratamento tributário diferenciado às MP e EPP. Também foi acrescentado ao artigo 146 o parágrafo único, que permitiu a instituição de um regime único, opcional para o contribuinte, de arrecadação dos impostos e contribuições da União, dos Estados, do Distrito Federal e dos Municípios. O parágrafo único, com seus incisos, delineou o que viria a ser o regime tributário do Simples Nacional, com a previsão do recolhimento unificado e centralizado, da distribuição incondicional das respectivas parcelas, da fiscalização compartilhada e do cadastro unificado. Também foi acrescentado o artigo 146-A, que assim dispõe:

“Art. 146-A. Lei complementar poderá estabelecer critérios especiais de tributação, com o objetivo de prevenir desequilíbrios da concorrência, sem prejuízo da competência de a União, por lei, estabelecer normas de igual objetivo."

Este artigo também é um dos fundamentos do regime do Simples Nacional. Aqui se trata não apenas do tratamento específico das MPE, 
como também da utilização da tributação diferenciada como instrumento de defesa da livre concorrência. $\mathrm{O}$ que se pretende com este dispositivo é possibilitar às empresas menores ingressarem no mercado e permanecerem nele, uma vez que as grandes empresas, em função do seu volume de negócios, podem operar com margens menores de lucro unitário, bem como conseguir preços menores dos seus fornecedores. Essas e outras vantagens comparativas poderiam inviabilizar a existência das pequenas empresas, bem como favorecer a formação de monopólios e oligopólios em determinados setores. Assim, o regime diferenciado de tributação para as MPE atende perfeitamente ao objetivo de prevenir desequilíbrios da concorrência.

Uma discussão interessante, que foi travada quando da promulgação da EC 42/2003 e da elaboração da Lei Geral, dizia respeito à constitucionalidade de normas editadas pela União que venham a instituir critérios obrigatórios de tributação para os Estados e Municípios. Alguns doutrinadores vislumbraram nisso uma violação da autonomia constitucional dos entes federativos, uma vez que o autogoverno, um dos elementos fundamentais da autonomia, só se torna efetivo quando o ente tem competência para instituir e cobrar seus próprios tributos, ou seja, quando existe a efetiva autonomia financeira do ente federativo. Em sentido oposto, outros entenderam que as novas normas constitucionais relativas às MPE, introduzidas pela EC 42/2003, vieram tornar efetivo o tratamento favorecido previsto já no texto original, nos artigos 170, IX, e 179.

Em favor da primeira posição, poder-se-ia argumentar que o artigo 170, quando fala de tratamento favorecido às MPE, não diz respeito especificamente ao tratamento tributário, mas ao tratamento econômico. Ou seja, tal dispositivo trataria da adoção de regras favoráveis às MPE em aspectos como a participação em licitações públicas, a contratação com o poder público, a obtenção de crédito e a regulação dos mercados. 
Também se poderia argumentar que o artigo 179, que fala especificamente do tratamento tributário diferenciado, especifica os entes federativos (a União, os Estados, os Municípios e o Distrito Federal) que estabelecerão leis tendentes a reduzir ou eliminar as obrigações da MPE. Daí se poderia depreender que, necessariamente, cada ente federativo teria a incumbência de definir, através de lei, as obrigações que seriam reduzidas ou eliminadas, conforme a competência do ente legislante. Ou seja, a União só poderia reduzir ou eliminar obrigações relativas à sua própria competência administrativa e tributária.

Sem pretender analisar de forma mais profunda tal discussão, podemos encontrar no artigo 146-A a chave para eliminar uma possível antinomia. A livre concorrência, conforme o texto constitucional originário, é um dos princípios básicos da ordem econômica (artigo 170, IV). Como dito anteriormente, o artigo 146-A representa a projeção desse princípio no sistema tributário nacional, uma vez que as normas tributárias diferenciadas são um mecanismo essencial para assegurar a participação das empresas menores no mercado. Ora, sem a criação de um regime tributário único, compartilhado por todos os entes tributantes, não haveria como conferir efetividade ao princípio em questão. $\mathrm{Na}$ verdade, a própria multiplicidade de normas é um dos grandes obstáculos enfrentados pelas empresas de estrutura mais modesta.

Daí se pode concluir que o Estatuto Nacional da Microempresa e da Empresa de Pequeno Porte, bem como o seu correspondente suporte constitucional construído pela EC 42/2003, ao invés de afrontar, concretiza os princípios constitucionais já expressos no texto originário, no que diz respeito aos fundamentos da ordem econômica nacional. $\mathrm{O}$ tratamento diferenciado das MPE, inclusive no aspecto tributário, é um instrumento indispensável para a defesa da livre concorrência e para o equilíbrio dos mercados. 


\section{3 - Regimes anteriores ao Simples Nacional}

Até 1984, legislações esparsas, nos três níveis de governo, estabeleciam alguns benefícios para as assim chamadas empresas de reduzida receita bruta. $\mathrm{O}$ primeiro estatuto nacional da microempresa foi instituído pela Lei 7.256/84. Para as empresas com receita bruta até 10 mil ORTN, correspondentes hoje a aproximadamente 108 mil reais, e não alcançadas pelas vedações do seu artigo $3^{\circ}$, a lei concedia isenção de diversos tributos federais. A lei concedia ainda a dispensa de diversas obrigações burocráticas, procedimento especial de registro, simplificação de obrigações trabalhistas e apoio creditício.

Logo em seguida, esse estatuto teve seu alcance ampliado pela LC 48/84, que isentava as microempresas do ICM (atual ICMS) e do ISS, mas deixava aos Estados e Municípios a atribuição de definir o conceito de microempresa em suas áreas de atuação. Dessa forma, o número de empresas que podiam usufruir dos benefícios da LC 48/84 era relativamente baixo, pois os entes federativos, ao estabelecerem seus respectivos regimes aplicáveis às microempresas, tinham a possibilidade de estabelecer uma série de limitações que restringiam bastante o universo de empresas aptas a obter o enquadramento. Vale lembrar que, no regime constitucional então vigente, a lei complementar podia instituir isenção heterônoma.

A Lei 8.864/94, que introduziu o conceito de Empresa de Pequeno Porte, previsto na Constituição de 1988, estabeleceu normas de tratamento diferenciado e simplificado nos campos administrativo, fiscal, previdenciário, trabalhista, creditício e de desenvolvimento empresarial. Os efeitos tributários dessa lei, no entanto, dependiam de regulamentação do Poder Executivo, que nunca chegou a ser editada.

A Lei 9.841/99 instituiu o Estatuto da Microempresa e da Empresa de Pequeno Porte, que cuidava basicamente da definição de ME e EPP e dos requisitos para o enquadramento, além da concessão de alguns 
benefícios extrafiscais, principalmente no que diz respeito ao crédito e ao desenvolvimento empresarial.

Quanto aos aspectos tributários, fora editada a Lei 9.317/96, que criou o Simples Federal, um regime simplificado de pagamento de impostos e contribuições para as MPE, mas aplicável apenas aos tributos federais. Entre os principais benefícios da lei estavam o recolhimento de vários tributos em um único documento e a simplificação das obrigações acessórias. O regime não abrangia a maior parte das atividades de prestação de serviços, uma vez que o artigo $9^{\circ}$, XIII, vedava o ingresso no regime de atividades relativas a profissões cujo exercício depende de habilitação profissional específica, tal como já ocorria nas leis anteriores. A participação dos Estados e Municípios no regime não era obrigatória, mas era possível mediante convênio. O regime estabelecia alíquotas diferenciadas para ME e EPP, conforme a faixa de receita bruta. $\mathrm{O}$ alcance do Simples Federal foi ampliado pela Lei 10.034/00 e pela Lei 10.684/03, que retiraram algumas atividades de prestação de serviços do alcance da vedação prevista no citado artigo $9^{\circ}$, XIII.

Após a promulgação da EC 42/2003, começaram as discussões sobre a instituição do regime unificado para as ME e EPP. Os parâmetros do regime, como já citado, foram definidos no parágrafo único do artigo 146, acrescentado pela Emenda. Seguindo esses parâmetros, após intensos debates entre as instâncias representativas da administração fazendária dos três níveis de governo, foi editada, em 14 de dezembro de 2006, a Lei Complementar 123/06, que instituiu o Estatuto Nacional da Microempresa e da Empresa de Pequeno Porte. As Leis Complementares 127/07 e 128/08 introduziram modificações relevantes, que complementaram o regime e ampliaram seu alcance, conforme será analisado nos capítulos seguintes. 


\section{Capítulo 2 - Aspectos gerais do Simples Nacional}

\section{1 - Coordenação e regulamentação do sistema}

A LC 123/06, também chamada de Lei Geral das Micro e Pequenas Empresas (LG), previu a criação de um órgão centralizador, encarregado de coordenar e de baixar as normas complementares necessárias ao funcionamento do regime diferenciado de tributação, o Comitê Gestor de Tributação das Microempresas e Empresas de Pequeno Porte, hoje chamado de Comitê Gestor do Simples Nacional (CGSN), instituído pelo Decreto 6.038/07, e composto por 4 representantes da União, 2 dos Estados e do Distrito Federal e 2 dos Municípios. Esse Comitê, presidido e coordenado por um dos representantes da União, regula os aspectos tributários da LG. Quanto aos demais aspectos, o órgão de coordenação é o Fórum Permanente das Microempresas e Empresas de Pequeno Porte, além do Comitê para Gestão da Rede Nacional para a Simplificação do Registro e da Legalização de Empresas e Negócios.

O CGSN também é responsável por apreciar a necessidade de revisão dos valores expressos em moeda na LG. Até o momento, os valores em questão continuam inalterados, tendo já sido publicada uma resolução do CGSN, de número 65/2009, que considerou não haver necessidade de revisão.

Desde a sua criação, o CGSN já editou 73 resoluções, regulando diversos aspectos do sistema. A maior parte das resoluções se refere a alterações de resoluções anteriores. Algumas resoluções dizem respeito à estrutura do CGSN e a aspectos técnicos da administração do sistema. Outras se referem à adoção pelos Estados e Municípios de sublimites para efeito de cálculo do ICMS e do ISS, em exercícios específicos. À parte os casos acima, as principais resoluções do CGSN que, com suas alterações, conformam o atual sistema do Simples Nacional são: 
04/2007 - opção pelo regime do Simples Nacional.

10/2007 - obrigações acessórias das ME e EPP optantes.

11/2007 - arrecadação e partilha dos tributos.

13/2007 - processo de consulta tributária.

15/2007 - exclusão do regime do Simples Nacional.

30/2008 - fiscalização, lançamento e contencioso administrativo.

34/2008 - processos judiciais relativos ao Simples Nacional.

38/2008 - forma opcional de determinação da base de cálculo.

39/2008 - processo de restituição.

51/2008 - cálculo e recolhimento dos tributos devidos pelas ME e EPP optantes (esta resolução revogou a de $n^{\circ}$ 05/2007, sem interrupção de sua força normativa no que diz respeito aos fatos geradores já ocorridos; a nova resolução passou a produzir efeitos a partir de $1^{\circ}$ de janeiro de 2009).

52/2008 - benefícios fiscais relativos ao ICMS e ao ISS.

58/2009 - Microempreendedor Individual.

\section{2 - Tributos abrangidos pelo Simples Nacional}

De acordo com o artigo 13 da LG, o regime do Simples Nacional abrange o recolhimento unificado, ou seja, em uma única guia de recolhimento, dos seguintes tributos:

1- Imposto sobre a Renda da Pessoa Jurídica - IRPJ;

2- Imposto sobre Produtos Industrializados - IPI;

3- Contribuição Social sobre o Lucro Líquido - CSLL;

4- Contribuição para o Financiamento da Seguridade Social COFINS;

5- Contribuição para o PIS/PASEP;

6- Contribuição Patronal Previdenciária - CPP; 
7- Imposto sobre a Circulação de Mercadorias e Serviços - ICMS;

8- Imposto sobre Serviços de Qualquer Natureza - ISS.

Os tributos acima elencados têm em comum o fato de serem cobrados periodicamente das empresas, além do fato de estarem diretamente ligados à atividade produtiva. Não foram incluídos no regime simplificado impostos sobre o patrimônio, sobre operações financeiras, sobre o comércio exterior (que têm finalidade regulatória, e não arrecadatória), sobre ganhos eventuais, além de outras hipóteses específicas previstas na LG. Também não estão incluídas no regime geral as taxas cobradas pelas três esferas de governo, nos seus respectivos âmbitos de atuação. A lógica do sistema é que os tributos cujos fatos geradores são esporádicos, não ligados à receita operacional, não são abrangidos pelo regime geral.

Conforme o artigo 13, $\S 3^{\circ}$, da LG, as MPE optantes pelo Simples Nacional foram dispensadas das demais contribuições instituídas pela União, inclusive as contribuições para o sistema "S" e para fundos e entidades ligadas às diversas categorias. Ainda não é pacífico o entendimento sobre a dispensa da Contribuição Sindical Patronal e do salário-educação, uma vez que essas contribuições não são expressamente citadas na $\mathrm{LG}^{2}$. No entanto, ainda na vigência do Simples Federal, a RFB, conforme consta da Instrução Normativa 608/06, já entendia que as MPE estavam dispensadas de tais tributos.

Já o artigo 14 considerou isentos do imposto de renda os valores distribuídos aos sócios das MPE, exceto quando correspondentes a aluguéis, pró-labore ou serviços prestados.

\footnotetext{
${ }^{2} \S 3^{\circ}$ As microempresas e empresas de pequeno porte optantes pelo Simples Nacional ficam dispensadas do pagamento das demais contribuições instituídas pela União, inclusive as contribuições para as entidades privadas de serviço social e de formação profissional vinculadas ao sistema sindical, de que trata o art. 240 da Constituição Federal, e demais entidades de serviço social autônomo.
} 


\section{3 - O conceito de micro e pequena empresa}

O principal critério para definição das empresas abrangidas pelo conceito de MPE é o da receita bruta. Assim, consideram-se microempresas aquelas com receita bruta anual de até 240 mil reais, e empresas de pequeno porte aquelas com receita bruta anual entre 240 mil e 2 milhões e 400 mil reais. Para fins de enquadramento na condição de ME e EPP, não se incluem no cômputo as receitas financeiras, e deve ser considerada a soma das receitas de todos os estabelecimentos pertencentes à empresa. No caso do ano de início de atividade, o limite será considerado proporcionalmente ao número de meses ou fração a partir da inscrição.

Alguns estados podem optar, até o último dia útil do mês de outubro de cada ano, por adotar sublimites de receita bruta anual, para efeito de recolhimento do ICMS, com efeitos para o exercício subseqüente. Nesse caso, o sublimite também valerá para os Municípios correspondentes, para efeito de recolhimento do ISS. Quando a empresa ultrapassar o respectivo sublimite estadual (que pode ser de 1 milhão e 800 mil reais ou de 1 milhão e 200 mil reais, conforme a participação do Estado no PIB nacional), ficará impedida de recolher o ICMS e o ISS na forma do Simples Nacional, no ano subseqüente. Os Estados com participação no PIB igual ou superior a $5 \%$ não poderão adotar sublimites de receita bruta.

Além do critério da receita bruta, a LG também previu situações em que as empresas não se enquadram no conceito de ME e EPP, uma vez que tais situações não correspondem ao espírito e ao objetivo da $\mathrm{Lei}^{3}$. Uma das

\footnotetext{
${ }^{3} \mathrm{O}$ artigo $3^{\circ}, \S 4^{\circ}$, exclui da definição de ME e EPP as seguintes empresas:

I - de cujo capital participe outra pessoa jurídica;

II - que seja filial, sucursal, agência ou representação, no País, de pessoa jurídica com sede no exterior;

III - de cujo capital participe pessoa física que seja inscrita como empresário ou seja sócia de outra empresa que receba tratamento jurídico diferenciado nos termos desta Lei Complementar, desde que a receita bruta global ultrapasse o limite de $\mathrm{R} \$ 2.400 .000,00$;

IV - cujo titular ou sócio participe com mais de $10 \%$ (dez por cento) do capital de outra empresa não beneficiada por esta Lei Complementar, desde que a receita bruta global ultrapasse o limite de R\$ 2.400.000,00;
} 
principais motivações dessas exclusões é evitar o planejamento tributário, que poderia resultar, por exemplo, na subdivisão de grandes empresas em várias empresas de menor porte, bem como em várias composições societárias que acabariam por desvirtuar o objetivo da Lei, alcançando contribuintes cuja condição econômica não justifica a concessão de tratamento diferenciado.

\section{4 - Vedações ao ingresso no sistema}

Além das restrições constantes do artigo $3^{\circ}, \S 4^{\circ}$, no que diz respeito ao enquadramento como ME e EPP, o artigo 17 da LG estabelece uma série de vedações ao ingresso no regime do Simples Nacional. A lista de vedações, inicialmente, gerou algumas dúvidas e polêmicas, que levaram à sua alteração pela LC 128/08. Cabe destacar que, aqui, as empresas consideradas podem ser enquadradas como ME e EPP, desde que atendam à definição do artigo $3^{\circ}$, e usufruir dos diversos benefícios previstos na LG, mas não poderão recolher os tributos devidos na forma do regime simplificado, por razões pertinentes à Administração Tributária.

As vedações se destinam, principalmente, a evitar perdas substanciais na arrecadação de determinados tributos, como a contribuição previdenciária patronal, o IPI sobre produtos que concentram grande parte da arrecadação desse imposto, bem como os tributos incidentes sobre atividades de transportes, produção e distribuição de energia elétrica, telecomunicações, incorporação de imóveis, entre outras.

$\mathrm{V}$ - cujo sócio ou titular seja administrador ou equiparado de outra pessoa jurídica com fins lucrativos, desde que a receita bruta global ultrapasse o limite de R $\$ 2.400 .000,00$;

VI - constituída sob a forma de cooperativas, salvo as de consumo;

VII - que participe do capital de outra pessoa jurídica;

VIII - que exerça atividade de banco comercial, de investimentos e de desenvolvimento, de caixa econômica, de sociedade de crédito, financiamento e investimento ou de crédito imobiliário, de corretora ou de distribuidora de títulos, valores mobiliários e câmbio, de empresa de arrendamento mercantil, de seguros privados e de capitalização ou de previdência complementar;

IX - resultante ou remanescente de cisão ou qualquer outra forma de desmembramento de pessoa jurídica que tenha ocorrido em um dos 5 (cinco) anos-calendário anteriores;

$\mathrm{X}$ - constituída sob a forma de sociedade por ações. 
Muitas atividades de serviços foram excluídas da possibilidade de optar pelo regime. Entre os motivos para isso, podemos apontar: maior dificuldade de fiscalizar a receita; inaplicabilidade do conceito de receita bruta para a prestação de serviços, pois não há custo de mercadorias adquiridas para a revenda; muitas "empresas" prestadoras de serviços são, na verdade, formas de apresentação da própria atividade individual do prestador de serviços, e aí não há geração de empregos e nem mesmo a empresa no sentido clássico do termo ${ }^{4}$.

Cabe ressaltar que a LG não veda a inclusão das sociedades simples no regime simplificado. Ocorre que, de um modo geral, as atividades típicas de sociedades simples com finalidade econômica, normalmente ligadas à prestação de serviços de caráter técnico, intelectual ou de intermediação, estão excluídas do regime, com exceção de algumas atividades, conforme

\footnotetext{
${ }^{4} \mathrm{Na}$ forma do artigo 17 , não pode optar pelo regime simplificado a ME ou EPP:

I - que explore atividade de prestação cumulativa e contínua de serviços de assessoria creditícia, gestão de crédito, seleção e riscos, administração de contas a pagar e a receber, gerenciamento de ativos (asset management), compras de direitos creditórios resultantes de vendas mercantis a prazo ou de prestação de serviços (factoring);

II - que tenha sócio domiciliado no exterior;

III - de cujo capital participe entidade da administração pública, direta ou indireta, federal, estadual ou municipal;

IV - que possua débito com o Instituto Nacional do Seguro Social - INSS, ou com as Fazendas Públicas Federal, Estadual ou Municipal, cuja exigibilidade não esteja suspensa;

$\mathrm{V}$ - que preste serviço de transporte intermunicipal e interestadual de passageiros;

VI - que seja geradora, transmissora, distribuidora ou comercializadora de energia elétrica;

VII - que exerça atividade de importação ou fabricação de automóveis e motocicletas;

VIII - que exerça atividade de importação de combustíveis;

IX - que exerça atividade de produção ou venda no atacado de:

a) cigarros, cigarrilhas, charutos, filtros para cigarros, armas de fogo, munições e pólvoras, explosivos e detonantes;

b) bebidas a seguir descritas:

1 - alcoólicas;

2 - refrigerantes, inclusive águas saborizadas gaseificadas;

3 - preparações compostas, não alcoólicas (extratos concentrados ou sabores concentrados), para elaboração de bebida refrigerante, com capacidade de diluição de até 10 (dez) partes da bebida para cada parte do concentrado;

4 - cervejas sem álcool;

$\mathrm{X}$ - que tenha por finalidade a prestação de serviços decorrentes do exercício de atividade intelectual, de natureza técnica, científica, desportiva, artística ou cultural, que constitua profissão regulamentada ou não, bem como a que preste serviços de instrutor, de corretor, de despachante ou de qualquer tipo de intermediação de negócios;

XI - que realize cessão ou locação de mão-de-obra;

XII - que realize atividade de consultoria;

XIII - que se dedique ao loteamento e à incorporação de imóveis.

XIV - que realize atividade de locação de imóveis próprios, exceto quando se referir à prestação de serviços tributados pelo ISS.”
} 
estabelecido no artigo $18, \S \S 5^{\circ}-\mathrm{B}$ a $5^{\circ}-\mathrm{F}$. Um caso notável é o dos escritórios de contabilidade, que têm a manutenção do enquadramento vinculada ao cumprimento de algumas obrigações, previstas no artigo 18, que têm o objetivo de melhorar o funcionamento do sistema de tributação do Simples Nacional. ${ }^{5}$

A exigência de quitação dos débitos tributários e previdenciários foi amenizada pela LC 127/07, que instituiu um parcelamento especial para ingresso no Simples Nacional, em até 120 parcelas mensais, nos termos do artigo 79 da LG.

\section{5 - Requisitos para o ingresso no sistema}

Para ingressar no regime diferenciado, a pessoa jurídica deve atender aos seguintes requisitos, de forma cumulativa:

a) estar enquadrada no conceito de ME ou de EPP;

b) estar inscrita no CNPJ e no respectivo Município, bem como no Estado, se exigível (no caso dos contribuintes do ICMS);

c) não incorrer em nenhuma das vedações previstas no artigo 17;

d) formalizar sua opção na forma e no prazo definido na legislação.

Nos termos da Resolução CGSN 04/2007, a opção deverá ser realizada, através da Internet, até o último dia útil do mês de janeiro, com eficácia a partir do primeiro dia do ano-calendário da opção. No caso de

\footnotetext{
5 § 22-B. Os escritórios de serviços contábeis, individualmente ou por meio de suas entidades representativas de classe, deverão:

I - promover atendimento gratuito relativo à inscrição, à opção de que trata o art. 18-A desta Lei Complementar e à primeira declaração anual simplificada da microempresa individual, podendo, para tanto, por meio de suas entidades representativas de classe, firmar convênios e acordos com a União, os Estados, o Distrito Federal e os Municípios, por intermédio dos seus órgãos vinculados;

II - fornecer, na forma estabelecida pelo Comitê Gestor, resultados de pesquisas quantitativas e qualitativas relativas às microempresas e empresas de pequeno porte optantes pelo Simples Nacional por eles atendidas;

III - promover eventos de orientação fiscal, contábil e tributária para as microempresas e empresas de pequeno porte optantes pelo Simples Nacional por eles atendidas.
} 
início de atividade, o prazo para realizar a opção, com efeitos já no primeiro ano, é de trinta dias após o deferimento da última inscrição necessária para o início do funcionamento, seja ela estadual, municipal ou no CNPJ.

As empresas que já estavam enquadradas no Simples Federal, quando do início da vigência do Simples Nacional, foram automaticamente transferidas para o novo regime, desde que não incorressem nas vedações previstas neste.

A opção pelo regime é irretratável para todo o ano-calendário em que é formalizada. Ou seja, a empresa só poderá optar pela exclusão do regime a partir do ano subseqüente. Uma vez ingressando no Simples Nacional, a empresa permanecerá nele por prazo indeterminado, não sendo preciso renovar a opção a cada ano. A saída do regime só ocorre por opção devidamente formalizada, por comunicação obrigatória, por exclusão de ofício ou por decisão judicial.

\section{6 - Exclusão do sistema}

À parte a exclusão por decisão judicial, existem três formas básicas de exclusão de uma ME ou EPP do regime do Simples Nacional:

1- por opção: neste caso, a empresa, de forma espontânea, decide não mais fazer parte do regime. A opção terá validade a partir do exercício seguinte, exceto quando manifestada no mês de janeiro, quando a validade será retroativa ao primeiro dia do exercício.

2- por comunicação obrigatória: quando a empresa passa a incorrer em uma das vedações previstas no artigo 17, ou quando ultrapassa, no exercício anterior, o limite de receita bruta relativo à EPP; a comunicação também é obrigatória quando a empresa, no ano de início de atividade, ultrapassa o limite de receita bruta relativo à EPP, proporcionalmente ao número de meses a partir da inscrição. 
3- de ofício: cabível quando deixar de ocorrer a comunicação obrigatória, ou quando ocorrer uma das infrações previstas nos incisos II a XII do artigo $29^{6}$. A exclusão de ofício terá efeito imediato, e impedirá a opção pelo regime do Simples Nacional nos 3 exercícios seguintes, ou nos 10 exercícios seguintes quando constatada a ocorrência de fraude.

\section{7 - Fiscalização e penalidades}

A fiscalização dos tributos relativos ao Simples Nacional é compartilhada pelas administrações tributárias da União e dos Estados ou do Distrito Federal, conforme a localização do estabelecimento, e também dos Municípios, quando houver prestação de serviços sujeitos ao ISS ou ainda quando houver convênio celebrado com o respectivo Estado. O lançamento de ofício, inclusive no que toca às penalidades, será efetuado pela autoridade que realizou a fiscalização, abrangendo todos os tributos

${ }^{6}$ Art. 29. A exclusão de ofício das empresas optantes pelo Simples Nacional dar-se-á quando:

I - verificada a falta de comunicação de exclusão obrigatória;

II - for oferecido embaraço à fiscalização, caracterizado pela negativa não justificada de exibição de livros e documentos a que estiverem obrigadas, bem como pelo não fornecimento de informações sobre bens, movimentação financeira, negócio ou atividade que estiverem intimadas a apresentar, e nas demais hipóteses que autorizam a requisição de auxílio da força pública;

III - for oferecida resistência à fiscalização, caracterizada pela negativa de acesso ao estabelecimento, ao domicílio fiscal ou a qualquer outro local onde desenvolvam suas atividades ou se encontrem bens de sua propriedade;

IV - a sua constituição ocorrer por interpostas pessoas;

V - tiver sido constatada prática reiterada de infração ao disposto nesta Lei Complementar;

VI - a empresa for declarada inapta, na forma dos arts. 81 e 82 da Lei no 9.430, de 27 de dezembro de 1996, e alterações posteriores;

VII - comercializar mercadorias objeto de contrabando ou descaminho;

VIII - houver falta de escrituração do livro-caixa ou não permitir a identificação da movimentação financeira, inclusive bancária;

IX - for constatado que durante o ano-calendário o valor das despesas pagas supera em $20 \%$ (vinte por cento) o valor de ingressos de recursos no mesmo período, excluído o ano de início de atividade;

$\mathrm{X}$ - for constatado que durante o ano-calendário o valor das aquisições de mercadorias para comercialização ou industrialização, ressalvadas hipóteses justificadas de aumento de estoque, for superior a $80 \%$ (oitenta por cento) dos ingressos de recursos no mesmo período, excluído o ano de início de atividade.

XI - houver descumprimento da obrigação contida no inciso I do caput do art. 26 desta Lei Complementar;

XII - omitir da folha de pagamento da empresa ou de documento de informações previsto pela legislação previdenciária, trabalhista ou tributária, segurado empregado, trabalhador avulso ou contribuinte individual que lhe preste serviço. 
incluídos no regime, sejam ou não de competência tributária do ente autuante. Para evitar duplicidade de autuações, foi estabelecido um Sistema Eletrônico Único de Fiscalização, no qual serão registradas as ações fiscais relativas ao Simples Nacional, nos termos da Resolução CGSN 30/2008. Os entes federativos também são competentes para efetuar a exclusão de ofício quando o contribuinte exercer atividades incluídas na sua esfera de competência tributária, nos termos da Resolução CGSN 15/2008.

No caso de impugnação de lançamento ou de recurso contra a exclusão de ofício, a competência para o julgamento administrativo será do ente federativo que realizou o lançamento ou a exclusão. Uma exceção a essa regra é o caso em que, sendo a empresa contribuinte tanto do ICMS quanto do ISS, não seja possível identificar a origem da receita omitida. Nesse caso, será utilizada a maior alíquota prevista entre as aplicáveis, a parcela da autuação relativa àquela receita será rateada entre o estado e o município correspondentes e o julgamento da eventual impugnação será de competência do estado.

A principal penalidade específica do Simples Nacional é a exclusão de ofício, já detalhada no tópico anterior. A falta de comunicação da exclusão, quando obrigatória, acarreta multa de $10 \%$ do total dos tributos devidos no último mês em que a empresa não estava sujeita à exclusão, no valor mínimo de duzentos reais. No caso do MEI, a multa está fixada em cinqüenta reais. No caso de simples falta de pagamento dos valores decorrentes do regime simplificado, os acréscimos moratórios e a multa de ofício seguem as regras previstas na legislação do imposto de renda, mesmo quando o lançamento incluir o ICMS e o ISS.

No caso de falta de apresentação da declaração simplificada anual nos prazos estabelecidos na legislação, a multa é de $2 \%$ sobre o montante total relativo ao período a ser declarado, multiplicado pelo número de meses ou fração em atraso, não superior a $20 \%$ do montante total e não inferior a duzentos reais. No caso do MEI, a multa mínima é de cinqüenta 
reais. Esta infração só pode ser autuada pela RFB, uma vez que, em relação às obrigações acessórias, a autuação é de competência da administração tributária junto à qual a obrigação deveria ser cumprida.

\section{8 - Processo Judicial}

Embora os Estados e Municípios sejam competentes para fazer o lançamento em determinados casos, a cobrança judicial será feita pela União, através da Procuradoria-Geral da Fazenda Nacional (PGFN). Esta poderá, entretanto, delegar aos Estados e Municípios, mediante convênio, a competência para inscrever em dívida ativa e cobrar judicialmente os tributos estaduais e municipais incluídos no Simples Nacional.

No caso de ação movida pelo contribuinte, relativa a tributo incluído no regime ou a ato do CGSN que regulamente o Simples Nacional, o pólo passivo será ocupado pela União, representada pela PGFN, exceto no caso de mandado de segurança impetrado em face de autoridade estadual ou municipal, ou de ação que se refira exclusivamente a tributo estadual ou municipal. 


\section{Parte II}

\section{Capítulo 3 - Efeitos do novo regime para os contribuintes}

\section{1 - Cálculo e recolhimento dos tributos}

Uma vez que o Simples Nacional abrange diversos tributos, diversas espécies de atividade econômica e diversos perfis empresariais, existem numerosas regras específicas e várias tabelas de cálculo, aplicáveis às várias situações possíveis, conforme a atividade, o volume de receita e outras especificidades relativas às empresas integrantes do regime. A descrição e a explicação de todas estas situações, bem como a apresentação de exemplos de cálculo aplicáveis aos diferentes casos, demandariam um trabalho específico sobre a matéria. Assim, este tópico é apenas um resumo das normas aplicáveis ao cálculo e ao recolhimento dos tributos, expondo suas linhas gerais e destacando algumas regras de particular relevância.

As normas relativas ao cálculo estão contidas nos artigos 18 a 20 da LG, além das tabelas de cálculo aplicáveis a cada espécie de atividade econômica, constantes dos Anexos I a V, que determinam a alíquota total aplicável a cada tipo de receita, bem como a parcela correspondente a cada tributo. Cabe ressaltar que as parcelas correspondentes ao ICMS e ISS podem ser objeto de isenção ou redução específica pelos entes tributantes competentes, e assim sofrerão a correspondente exclusão ou redução proporcional, quando da determinação da alíquota total aplicável. Os Estados e Municípios também podem adotar valores fixos de tributação para as microempresas com receita bruta até 120 mil reais, e esses valores constituirão as parcelas correspondentes ao ICMS e ao ISS. Também serão excluídas do cálculo as parcelas relativas a tributos sujeitos à imunidade ou a qualquer outra hipótese de não incidência. 
A multiplicidade de regras (o artigo 18, na redação inicial, continha 25 parágrafos, que já chegam atualmente a 37), de início, levou alguns contabilistas e tributaristas a comentarem que o Simples Nacional não era tão "simples" assim, pois seria difícil encontrar os valores a serem pagos e mesmo determinar se seria vantajoso para o contribuinte optar pelo regime diferenciado. No entanto, à medida que analisamos as regras do sistema, vemos que a questão não é tão complexa, pois, conforme a atividade exercida, apenas algumas dessas regras serão aplicáveis. Além disso, cada situação específica prevista no regime abrange apenas uma determinada parcela dos contribuintes.

Os tributos abrangidos pelo regime devem ser pagos em uma única guia, o Documento de Arrecadação do Simples Nacional (DAS), impresso através do Programa Gerador do Documento de Arrecadação do Simples Nacional (PGDAS), disponível apenas na Internet, no Portal do Simples Nacional. Nesse aplicativo de cálculo, as empresas optantes prestarão as informações necessárias à apuração do valor devido no mês considerado. Caso a ME ou EPP possua filiais, o recolhimento deverá ser efetuado através da matriz, e corresponderá ao somatório das receitas de todos os estabelecimentos. Os valores devidos por responsabilidade tributária serão recolhidos diretamente ao ente tributante, não sendo incluídos no cálculo do valor a ser recolhido através do DAS.

Até o mês de fevereiro de 2009, o pagamento deveria ser efetuado até o último dia útil da primeira quinzena do mês subseqüente àquele em que a receita foi auferida. A Resolução CGSN 56/2009 alterou o término do prazo para o dia 20 do mês subseqüente. Foram fixados, por diferentes resoluções do CGSN, prazos excepcionais de pagamento para alguns meses de apuração e para alguns casos específicos. No caso de recolhimento fora do prazo, os acréscimos moratórios seguem as regras previstas na legislação do imposto de renda. 
A base de cálculo para determinação do valor mensal a ser recolhido é a receita bruta total auferida em cada mês, segregada, para fins de inserção no PGDAS, conforme as atividades que originaram as diferentes receitas. A segregação também diz respeito a situações específicas, como as revendas nas quais houve substituição tributária e aquelas destinadas à exportação. No primeiro caso, será abatido da alíquota de ICMS aplicável o percentual do tributo sujeito à substituição tributária, uma vez que esse percentual já foi recolhido na origem. No caso das exportações, as vendas estarão dispensadas da parcela correspondente ao ICMS, e serão aplicadas apenas as alíquotas referentes aos demais tributos.

A partir de janeiro de 2009 , a receita bruta tributável pode ser apurada não apenas pelo regime de competência, mas também pelo regime de caixa. Quando da primeira apuração do ano correspondente, a empresa deve fazer a opção, que será irretratável para todo o ano-calendário.

$\mathrm{O}$ enquadramento das diversas receitas da empresa nas tabelas de cálculo depende da atividade à qual corresponda cada receita auferida. Assim, as revendas de mercadorias serão tributadas conforme a tabela do Anexo I. As atividades industriais se enquadram na tabela do Anexo II. As atividades de serviços foram divididas entre os Anexos III, IV e V, de acordo com o tipo específico de atividade, conforme previsto em diversos parágrafos do artigo 18. A atividade de locação de bens móveis se enquadra no Anexo III, estando dispensada da parcela relativa ao ISS. No caso dos serviços sujeitos ao ICMS, aplica-se o Anexo III, mas a parcela relativa ao ISS será substituída pela correspondente ao ICMS, prevista no Anexo I.

A alíquota aplicável é determinada pela faixa de receita bruta em que a empresa se enquadra, tomando por base os 12 meses anteriores ao período de apuração. Por exemplo, para encontrar a faixa pertinente ao mês de maio de 2010, deve-se apurar a receita bruta acumulada de maio de 2009 a abril de 2010. Quando a empresa estiver em atividade há menos de 12 meses, aplica-se a média dos meses anteriores multiplicada por 12, exceto no mês 
de início, quando se aplica a receita do próprio mês multiplicada por 12. Em cada uma das tabelas de cálculo aplicáveis às diferentes atividades, existem 20 faixas de receita bruta, cada uma correspondente a um incremento de 120 mil reais, até o limite de 2 milhões e 400 mil reais. Deve-se observar que a receita bruta considerada para determinar a faixa correspondente deve ser apurada pelo regime de competência.

As alíquotas aplicáveis aumentam conforme se sucedem as faixas de tributação. Para dar uma idéia da forma de cálculo, vamos considerar um caso bastante simples: uma empresa comercial, com receita bruta acumulada de 120 mil reais, cuja única atividade seja a revenda de mercadorias, sem exportação, substituição tributária ou outra situação específica. Essa empresa se enquadra na primeira faixa da tabela do Anexo I, e deverá pagar o valor correspondente a $4 \%$ da receita bruta do mês, sendo 2,75\% correspondente à CPP e 1,25\% ao ICMS, e ficando com alíquota zero para os demais tributos. Caso a receita acumulada seja de 125 mil reais, por exemplo, a empresa passa para a segunda faixa de tributação, e deverá pagar o correspondente a $5,47 \%$ da receita bruta do mês. Na faixa mais alta de tributação do comércio, próxima ao limite de enquadramento como EPP, a alíquota total aplicável é de 11,61\% sobre a receita bruta.

O valor total devido mensalmente pela empresa será a soma dos valores parciais, relativos a cada tipo de receita, observadas as normas aplicáveis a situações específicas.

\section{2 - Obrigações acessórias}

As obrigações acessórias, previstas na legislação tributária, são deveres instrumentais, de interesse da arrecadação e da físcalização dos tributos, como escriturar livros, emitir documentos, preencher declarações, entre outros. Sua inobservância pode convertê-las em obrigação principal, relativa ao pagamento da penalidade pecuniária. 
No caso do Simples Nacional, as obrigações acessórias foram regulamentadas pela Resolução CGSN 10/2007. A obrigação acessória mais importante para as MPE é a apresentação da declaração simplificada anual (DASN), que deve ser entregue à Receita Federal pela Internet, até o último dia do mês de março. A DASN deverá conter as informações sócioeconômicas e fiscais constantes do modelo aprovado pelo Comitê Gestor, e os dados declarados servirão como confissão de dívida, permitindo a inscrição em dívida ativa e posterior cobrança judicial dos créditos nela declarados e porventura não recolhidos. Nos casos de extinção, cisão, fusão, incorporação ou exclusão do Simples Nacional, a declaração simplificada deverá ser entregue até o último dia do mês seguinte ao do evento.

Em relação aos tributos abrangidos pelo regime, as empresas são obrigadas a emitir documentos fiscais, na forma regulamentada pelos entes federativos onde as MPE possuírem estabelecimentos, e mantê-los pelos cinco exercícios seguintes ao da emissão. As empresas deverão também escriturar e manter os seguintes livros físcais e contábeis, de acordo com a atividade exercida:

- livro Caixa, destinado ao registro de toda a movimentação financeira e bancária da empresa, dispensado caso a empresa possua os livros Diário e Razão devidamente escriturados;

- livro Registro de Inventário, no qual devem ser registrados os estoques existentes ao fim de cada exercício (apenas para os contribuintes do ICMS);

- livro Registro de Entradas (apenas para os contribuintes do ICMS);

- livro Registro dos Serviços Prestados (apenas para os contribuintes do ISS);

- livro Registro de Serviços Tomados (quando a empresa tomar serviços sujeitos à incidência do ISS e a legislação exigir a escrituração); 
- livro Registro de Entrada e Saída de Selo de Controle (apenas para determinados contribuintes do IPI);

- livros específicos para empresas que executem impressão de documentos fiscais, comércio de combustíveis ou intermediação de veículos.

Cabe ressaltar que a legislação específica de cada ente tributante pode isentar as MPE da escrituração de determinados livros fiscais. Apenas o livro Caixa (ou Diário e Razão), de natureza contábil, é obrigatório para todas as pessoas jurídicas.

\section{3 - O microempreendedor individual}

A LC 128/08 introduziu a figura do microempreendedor individual (MEI), assim entendido o empresário individual que, cumulativamente, possua receita bruta até 36 mil reais, seja optante pelo Simples Nacional, possua um único estabelecimento, não participe de outra empresa e não contrate empregado (exceto quando se tratar de um único empregado que receba exclusivamente um salário mínimo ou o piso salarial da categoria).

A criação desta categoria teve como objetivo permitir que profissionais autônomos de baixa renda e pequenos comerciantes, especialmente ambulantes, pudessem formalizar suas atividades, de modo a ter inscrição no CNPJ, o que lhes dá a possibilidade de emitir documento fiscal quando necessário, além de facilitar a abertura de contas bancárias e a concessão de empréstimos. Além disso, a inscrição como MEI permite que o contribuinte possa usufruir plenamente dos benefícios da previdência social, como aposentadoria por idade, auxílio-doença, auxílio-maternidade, entre outros.

A LC estabeleceu para o MEI, independentemente da receita efetiva de cada mês, o recolhimento de valores fixos mensais de $\mathrm{R} \$ 45,65$ a título de contribuição previdenciária, mais um real de ICMS, quando contribuinte, 
e cinco reais de ISS, quando contribuinte, sendo os valores atualizados anualmente conforme o reajuste do salário mínimo. O MEI está isento dos demais impostos e contribuições federais. Além disso, também está isento de eventuais taxas e emolumentos cobrados quando do processo de registro e licenciamento pelos entes federativos competentes.

\section{4 - Unificação dos cadastros e simplificação do registro}

Um dos conceitos mais importantes, no que toca à regularização das MPE, é o da unicidade do processo de registro e legalização. Os objetivos principais são os de evitar a duplicidade de exigências e de garantir a linearidade do processo, do ponto de vista do contribuinte. Busca-se, com isso, que a ME ou EPP não tenha que apresentar os mesmos documentos a órgãos diferentes e nem fique amarrada por exigências que impeçam o imediato início da atividade econômica, nos casos em que esta apresente baixo grau de risco. ${ }^{7}$

Uma das etapas fundamentais na criação de uma empresa são as pesquisas prévias às etapas de registro, antes da elaboração dos atos constitutivos, que são necessárias para que a empresa não tenha que refazer etapas e incorrer em custos desnecessários. Essas pesquisas têm por objeto:

- a possibilidade de exercício da atividade desejada no local escolhido, ou seja, sua adequação às normas urbanísticas;

${ }^{7}$ Art. $7^{\circ}$ Exceto nos casos em que o grau de risco da atividade seja considerado alto, os Municípios emitirão Alvará de Funcionamento Provisório, que permitirá o início de operação do estabelecimento imediatamente após o ato de registro.

Parágrafo único. Nos casos referidos no caput deste artigo, poderá o Município conceder Alvará de Funcionamento Provisório para o microempreendedor individual, para microempresas e para empresas de pequeno porte:

I - instaladas em áreas desprovidas de regulação fundiária legal ou com regulamentação precária; ou

II - em residência do microempreendedor individual ou do titular ou sócio da microempresa ou empresa de pequeno porte, na hipótese em que a atividade não gere grande circulação de pessoas.

Art. $8^{\circ}$ Será assegurado aos empresários entrada única de dados cadastrais e de documentos, resguardada a independência das bases de dados e observada a necessidade de informações por parte dos órgãos e entidades que as integrem. 
- a descrição oficial do endereço, que servirá como base para a elaboração dos atos constitutivos da empresa;

- os requisitos a serem cumpridos para obtenção de licenças de funcionamento;

- a possibilidade de uso do nome empresarial de seu interesse.

Nesse sentido, o artigo $5^{\circ}$ determinou que os três níveis de governo, conforme a atribuição de cada um, devem manter tais informações à disposição, de forma integrada e consolidada, inclusive na Internet, para que os interessados tenham segurança quanto à viabilidade do registro nas condições pretendidas.

Outros aspectos importantes da unicidade do registro são:

- simplificação e uniformização dos requisitos de segurança e de controle ambiental, sendo dispensada vistoria prévia de local quando o grau de risco da atividade assim o permitir;

- concessão de alvará provisório quando a atividade não for de alto risco, permitindo o início do funcionamento imediatamente após o registro;

- entrada única de dados cadastrais e de documentos, a fim de evitar a repetição de procedimentos em órgãos diferentes;

- inexigência de comprovação de quitação fiscal para registro, alteração e baixa da empresa nos órgãos competentes;

- inexigência de documentos adicionais, fora do estrito limite dos requisitos pertinentes à essência do ato de registro, alteração ou baixa. ${ }^{8}$

\footnotetext{
8 Art. 10. Não poderão ser exigidos pelos órgãos e entidades envolvidos na abertura e fechamento de empresas, dos 3 (três) âmbitos de governo:

I - excetuados os casos de autorização prévia, quaisquer documentos adicionais aos requeridos pelos órgãos executores do Registro Público de Empresas Mercantis e Atividades Afins e do Registro Civil de Pessoas Jurídicas;

II - documento de propriedade ou contrato de locação do imóvel onde será instalada a sede, filial ou outro estabelecimento, salvo para comprovação do endereço indicado;

III - comprovação de regularidade de prepostos dos empresários ou pessoas jurídicas com seus órgãos de classe, sob qualquer forma, como requisito para deferimento de ato de inscrição, alteração ou baixa de empresa, bem como para autenticação de instrumento de escrituração.
} 
A unicidade do processo ainda não foi totalmente implementada, pois muitas unidades federativas encontram dificuldades para se adequar às normas da LG. No caso do Município do Rio de Janeiro, já foram adotadas várias medidas de simplificação na obtenção de licenças de funcionamento, que serão analisadas no capítulo 4.

\section{5 - Normas empresariais e benefícios extrafiscais}

Além de criar o Simples Nacional, a LG, ao instituir o Estatuto Nacional da ME e da EPP, criou diversos benefícios extrafiscais, que abrangem inclusive os contribuintes que não queiram ou não possam ingressar no regime simplificado, desde que estes se enquadrem na definição de ME ou de EPP do artigo $3^{\circ}$ e seus parágrafos. Incluem-se entre esses benefícios a simplificação do processo de registro e de baixa, descrita no tópico anterior.

Nas licitações públicas, as MPE têm preferência na contratação, desde que suas propostas sejam iguais ou até $10 \%$ superiores à proposta mais bem classificada, exceto na modalidade de pregão, quando a diferença máxima será de 5\%. Nesses casos, bastará à ME ou EPP apresentar proposta de preço inferior àquela considerada vencedora para que obtenha a adjudicação do objeto da licitação. Outra vantagem para as MPE é a exigência da comprovação de regularidade fiscal apenas para efeito de assinatura do contrato, e não para mera participação no certame.

Uma importante inovação da LG é a criação da cédula de crédito microempresarial, dependente de regulamentação do Poder Executivo, que ainda não foi editada, embora já decorrido o prazo de 180 dias estabelecido na LG. Este título de crédito poderá ser emitido pela ME e EPP titular de

Art. 11. Fica vedada a instituição de qualquer tipo de exigência de natureza documental ou formal, restritiva ou condicionante, pelos órgãos envolvidos na abertura e fechamento de empresas, dos 3 (três) âmbitos de governo, que exceda o estrito limite dos requisitos pertinentes à essência do ato de registro, alteração ou baixa da empresa. 
direitos creditórios relativos a empenhos liquidados pela Administração Pública e não pagos em até trinta dias. Isso dará às MPE a possibilidade de negociar imediatamente tais créditos, tendo como lastro o empenho emitido pelo Poder Público, e evitando assim os prejuízos decorrentes do atraso no pagamento, que pode comprometer a própria capacidade de funcionamento da empresa.

$\mathrm{Na}$ esfera das relações trabalhistas, as MPE foram dispensadas de várias obrigações, como afixação do Quadro de Trabalho, anotação das férias dos empregados nos respectivos livros de registro e posse do livro "Inspeção do Trabalho". Também lhes foi facultado fazer-se representar perante a Justiça do Trabalho por terceiros (prepostos) que não possuam vínculo trabalhista ou societário com a empresa.

Outra importante previsão da LG é a fiscalização de natureza orientadora, que deverá ser adotada sempre que o grau de risco da atividade ou situação assim o permitir. Por essa sistemática, será utilizado o critério de dupla visita para lavratura de autos de infração, exceto nos casos de falta de registro de empregado ou de anotação da CTPS, ou quando houver reincidência, fraude, resistência ou embaraço à físcalização. Ou seja, na maioria das infrações, será dado à empresa um prazo para se adequar às exigências das autoridades competentes, antes da aplicação de penalidades.

No campo do associativismo, foi facultado às MPE, desde que optantes pelo Simples Nacional, constituir consórcios, por prazo indeterminado, com o objetivo de realizar negócios de compra e venda de bens e serviços para os mercados nacional e internacional. Isso dará às MPE maior poder de barganha e condições de competir frente a empresas de maior porte.

Também foram instituídas medidas de estímulo ao crédito e à capitalização e de apoio à inovação, que em sua maioria têm caráter de recomendação ou autorização, dependendo da ação dos órgãos e entidades públicas indicados na lei para sua efetivação. 
Alguns dos dispositivos da LG dizem respeito a normas empresariais aplicáveis às MPE, tendentes a facilitar e desonerar sua administração. $\mathrm{O}$ artigo 70 torna desnecessária a realização das reuniões e assembléias previstas para as demais empresas. $\mathrm{O}$ artigo 71 dispensa a publicação dos atos societários. $\mathrm{O}$ artigo 73 traz benefícios referentes ao pagamento de títulos levados a protesto. O artigo 74 autoriza as MPE a ajuizar causas perante os Juizados Especiais Cíveis. Para gozar dos benefícios legais, as MPE devem acrescentar ao seu nome empresarial as expressões "Microempresa" ou "Empresa de Pequeno Porte", ou ainda as respectivas abreviaturas, conforme o caso, nos termos do artigo 72 . 


\section{Capítulo 4 - As MPE no Município do Rio de Janeiro}

\section{1 - Antecedentes históricos na legislação municipal}

A LC 48/84, que integrou o primeiro estatuto nacional da microempresa, estabeleceu alguns benefícios para as microempresas relativos a tributos estaduais e municipais. No regime constitucional então vigente, era admissível a isenção heterônoma, desde que prevista em Lei Complementar. Cabia aos Estados e Municípios estabelecer os limites de receita e as condições necessárias para enquadramento como microempresa, atendidas duas condições: não resultarem em perda de arrecadação superior a 5\% da estimada para o imposto em questão e não ultrapassar o limite de receita estabelecido na lei federal. No caso dos Municípios, a LC previu a dispensa do imposto relativo à prestação de serviços (ISS), a redução das taxas ligadas ao exercício do poder de polícia e a simplificação das obrigações acessórias.

Para adaptar-se a esse estatuto, o Município do Rio de Janeiro editou a Lei 716/85. O limite de receita então adotado pela lei municipal, para fins de enquadramento no conceito de microempresa, idêntico ao limite provisório fixado pela LC $48 / 84$, era muito inferior ao atualmente adotado pela LG. O limite foi fixado, quando da publicação da lei, em 5 mil ORTN, que em valores atualizados para 2010 correspondem a cerca de 54 mil reais, sendo considerado, para fins de enquadramento, o valor total das receitas operacionais obtidas no ano anterior (ano-base).

Para os contribuintes novos ou que não tivessem funcionado no ano anterior, foi estabelecido, tal como ocorre no Simples Nacional, um limite proporcional ao número de meses a partir do início ou reinício da atividade. $\mathrm{O}$ enquadramento, nesses casos, seria condicional, ou seja, caso a receita bruta no ano inicial superasse o limite em mais de $5 \%$, o enquadramento 
não teria efeito e a empresa deveria recolher os tributos devidos desde o início da atividade.

A Lei 1.364/88 acrescentou ao estatuto municipal um Anexo Único, que instituiu várias vedações, além das já previstas no estatuto nacional, excluindo do regime de microempresa uma série de atividades de prestação de serviços, como representação comercial, produção de espetáculos, cinemas, boates e quaisquer tipos de diversões com cobrança de ingressos. A lista final de vedações ficou com quarenta incisos, cada um referente a uma atividade ou grupo de atividades.

As microempresas obtiveram os seguintes benefícios: isenção do ISS (o que não representava muita coisa, pois uma receita de 50 mil reais correspondia, geralmente, a um ISS anual de 2.500 reais); isenção da Taxa de Licença para Estabelecimento na obtenção do Alvará (atualmente em torno de 500 reais); e dispensa da escrituração do Livro de Registro do ISS. A perda da condição de microempresa só ocorreria quando a empresa ultrapassasse o limite de receita bruta por dois anos consecutivos ou por três anos alternados. Nos anos em que a receita ultrapassasse o limite, deveria ser pago o ISS sobre o excesso de receita a partir do mês em que este se verificasse.

Com a introdução do novo regime, criou-se um impasse em torno da subsistência da legislação municipal. A EC 42/2003, que estabeleceu as bases do que viria a ser o Simples Nacional, acrescentou ao ADCT o seguinte dispositivo:

“Art. 94. Os regimes especiais de tributação para microempresas e empresas de pequeno porte próprios da União, dos Estados, do Distrito Federal e dos Municípios cessarão a partir da entrada em vigor do regime previsto no art. 146, III, $d$, da Constituição."

Alguns doutrinadores vislumbraram nesse dispositivo uma violação do pacto federativo, uma vez que o constituinte derivado teria adentrado a competência tributária das demais unidades federativas. No entanto, o 
referido artigo apenas segue a regra constitucional de que o tratamento diferenciado das MPE será regulado pela Lei Complementar.

Efetivamente, a partir da entrada em vigor do Simples Nacional, várias unidades federativas, como no caso dos estados de Minas Gerais, São Paulo e Rio de Janeiro, revogaram seus regimes diferenciados de tributação. Não obstante isso, o Município do Rio de Janeiro manteve em vigor o seu estatuto da microempresa, considerando-o plenamente eficaz. A regulamentação infralegal, no entanto, determinou que a opção pelo Simples Nacional importa a exclusão do contribuinte do regime diferenciado municipal. Ou seja, a interpretação adotada pela autoridade tributária do Município foi a de que os dois regimes diferenciados (nacional e municipal) poderiam coexistir, mas um mesmo contribuinte não poderia participar de ambos.

\section{2 - Regulamentação do sistema no Município}

Até o momento, o Município do Rio de Janeiro adotou basicamente as regras já constantes da LG e das resoluções do CGSN, editando apenas algumas poucas normas, relativas a determinadas situações. Não houve dispensa específica de obrigações acessórias para as empresas optantes pelo Simples Nacional, ficando estas sujeitas a todas as obrigações previstas para os contribuintes do ISS, como emitir documentos fiscais e escriturar os livros especificados pela legislação. Entretanto, é interessante observar que algumas normas de simplificação editadas pelo Município, para fins de adaptação aos parâmetros da LG, acabaram por beneficiar não só as MPE, mas também as demais empresas e os profissionais autônomos sujeitos à fiscalização e à tributação pelo Município, como veremos no tópico seguinte.

A situação do MEI foi regulamentada pelo Decreto 30.588/09, que, em consonância com o previsto na LG, dispensou o MEI de pagamento da 
Taxa de Licença para Estabelecimento e da Taxa de Inspeção Sanitária relativas ao licenciamento inicial das atividades. O MEI fica obrigado a emitir documento fiscal apenas nas operações cujos destinatários sejam empresas regularmente inscritas no CNPJ e fica dispensado de manter os livros previstos na legislação tributária municipal. A possibilidade de emitir documento fiscal é uma vantagem importantíssima para o MEI, uma vez que, no Município do Rio de Janeiro, a emissão de nota fiscal foi vedada aos profissionais autônomos, nos termos do artigo $2^{\circ}, \S 2^{\circ}$, do Decreto $32.250 / 10$.

\section{3 - Cadastro e fiscalização das empresas}

O licenciamento das empresas em geral, bem como dos profissionais autônomos estabelecidos no Município do Rio de Janeiro, foi bastante facilitado pelo Decreto 30.568/09, que criou o Alvará Já. Trata-se de uma forma simplificada de obtenção do Alvará de Licença para Estabelecimento, para atividades de baixo risco sanitário e baixo impacto ambiental. No caso dessas atividades, quase todos os procedimentos necessários à obtenção do Alvará podem ser realizados através da Internet. Inicialmente, o contribuinte deverá fazer a Consulta Prévia de Local, de cuja reposta dependerá a elaboração dos atos constitutivos, pois nesse documento a Prefeitura informa se a atividade pretendida é ou não permitida no local. Com o número da Consulta aprovada, o contribuinte, ainda por meio da Internet, preencherá o requerimento padronizado, no qual será informado o número de inscrição no órgão de registro competente e no CNPJ. Após a aprovação do pedido, será disponibilizada, para impressão via Web, a guia para pagamento da Taxa de Licença para Estabelecimento, exceto nos casos de isenção.

No caso do licenciamento convencional, apenas a Consulta Prévia poderá ser feita por meio da Internet. O requerimento inicial padronizado e os demais documentos relacionados na resposta à Consulta Prévia deverão 
ser apresentados à Inspetoria Regional de Licenciamento e Fiscalização do bairro onde se localizará o estabelecimento.

Embora não seja voltado especificamente para as MPE, o Decreto segue os moldes da simplificação trazida pela LG, com foco na unicidade, na uniformidade e na integração dos procedimentos com os demais órgãos de registro, de modo a garantir a linearidade do processo. Por exemplo, quando suas atividades forem consideradas de baixo risco, todas as empresas ficam dispensadas de vistorias prévias ao início do funcionamento e, caso exigível, podem obter licença sanitária de forma simplificada, também através da Internet. Também foi introduzido processo simplificado para a obtenção da licença ambiental, quando exigível.

A fiscalização dos contribuintes do ISS no MRJ e o cumprimento das respectivas obrigações acessórias serão bastante otimizados e simplificados pela introdução da Nota Fiscal eletrônica, que será adotada de forma escalonada e será obrigatória para quase todos os contribuintes a partir de dezembro de 2010, conforme determinado pelo Decreto $32.250 / 10$ e pela Resolução SMF 2.617/10. Apenas as instituições financeiras, as empresas de transporte público de passageiros e de serviços de exploração de rodovias ficarão excluídas do sistema, além do MEI, para quem a adoção será facultativa.

Com a adoção da Nota Fiscal eletrônica, também chamada Nota Carioca, o contribuinte ficará dispensado de várias obrigações acessórias, como a escrituração do Livro de Registro do ISS, a autorização para impressão de documentos fiscais e a guarda de tais documentos, uma vez que estes estarão registrados em sistema informatizado. Várias atividades que antes demandavam o comparecimento do contribuinte ao plantão fiscal, como a correção de determinados dados lançados nos documentos e livros fiscais, poderão ser realizadas diretamente pela Internet. Apesar do custo inicial para a aquisição dos equipamentos necessários, as MPE terão uma diminuição expressiva dos custos de controle. 


\section{4 - Efeitos práticos na arrecadação municipal}

No Município do Rio de Janeiro, de aproximadamente 70 mil empresas contribuintes do ISS que tiveram recolhimento no ano de 2009, cerca de 28 mil (40\%) eram optantes pelo Simples Nacional. A arrecadação do ISS, relativa a esses contribuintes, foi de aproximadamente 2,68 bilhões de reais, sendo cerca de 136 milhões de reais relativos ao recolhimento pelo Simples Nacional. Cabe ressaltar que, no cadastro do Município do Rio de Janeiro, constam cerca de 50 mil empresas prestadoras de serviço com opção pelo Simples Nacional, mas aproximadamente 22 mil não apresentaram recolhimento. Ou seja, muitas empresas optantes não tiveram atividade no ano de 2009 ou estão em situação de inadimplência, o que exigirá a fiscalização e o lançamento dos tributos eventualmente devidos.

Existem 216 mil empresas com inscrição ativa no Município e que têm atividade de prestação de serviços. No entanto, muitas dessas empresas deixaram de funcionar e não comunicaram o encerramento das atividades. Outras funcionam de forma esporádica, tratando-se, na verdade, de pessoas físicas que, eventualmente, prestam um serviço cujo contratante exige a emissão de documento fiscal de pessoa jurídica (no sentido de pessoa com inscrição no CNPJ). O número de empresas nessa situação deve diminuir bastante com a criação do MEI, pois ficará mais claro quais são as inscrições que correspondem à atividade profissional do próprio titular, e não a empresas propriamente ditas.

No que se refere ao impacto do novo regime na arrecadação municipal, apresentamos os dados a seguir, relativos à receita total de ISS nos últimos 4 anos do MRJ, em valores atualizados para 2010. O total inclui o recolhimento de ISS pelos contribuintes do regime normal, da tributação por valores fixos (autônomos e sociedades uniprofissionais), do Simples Nacional, bem como dos responsáveis tributários: 
2006

$\mathrm{R} \$ 2.080 .582 .069,76$

2007 $\mathrm{R} \$ 2.290 .093 .828,15$

2008 $\mathrm{R} \$ 2.723 .716 .864,40$

2009 $\mathrm{R} \$ 2.937 .885 .466,06$

Como vemos, a arrecadação do ISS vem apresentando ganhos reais, mesmo no ano de 2009, em que houve uma pequena retração na atividade econômica nacional. A arrecadação relativa ao Simples Nacional responde por menos de $5 \%$ do total, embora alcance cerca de $40 \%$ dos contribuintes tributados com base no movimento econômico.

Esses dados demonstram que os maiores contribuintes respondem, de forma esmagadora, pela maior parte da arrecadação do ISS. Assim, a criação de regras simplificadas para as empresas menores, em vez de prejudicar, facilita o trabalho da Administração Tributária, pois permite que o controle e a fiscalização se concentrem nos contribuintes que têm maior impacto sobre a receita. 


\section{Conclusão}

Conforme foi analisado ao longo do trabalho, a introdução do Estatuto Nacional da Microempresa e da Empresa de Pequeno Porte, além de trazer benefícios significativos para as MPE, representou uma mudança de paradigma em muitos aspectos da arrecadação e da fiscalização tributária. $\mathrm{O}$ regime simplificado, à parte a questão específica dos valores a pagar, trouxe para as MPE uma significativa redução do custo da tributação, ou seja, do tempo e da estrutura necessária para controlar e pagar os tributos devidos. A própria Administração Tributária acaba por se beneficiar da nova situação, pois o estímulo à atividade econômica leva ao aumento da arrecadação e a simplificação torna mais ágil o funcionamento dos órgãos de fiscalização.

O exemplo apresentado no Capítulo 4 mostra que, ao contrário dos temores iniciais de Estados e Municípios em relação ao novo regime, a adoção de regras mais simples para as empresas menores pode, ao invés de prejudicar, facilitar o trabalho de arrecadação e fiscalização dos entes tributantes, visto que a receita de ISS do Município do Rio de Janeiro teve incrementos significativos.

Também é importante relembrar que a simplificação adotada no MRJ beneficiou não apenas as MPE, mas também as demais empresas e os profissionais autônomos, o que demonstra que o novo Estatuto pode ter um alcance ainda maior do que o previsto. Isso porque, aos poucos, a Administração Tributária vai se convencendo das vantagens da simplificação, eliminando controles desnecessários e focalizando seus recursos, muitas vezes escassos, no acompanhamento dos contribuintes que representam a parte mais significativa da arrecadação tributária

Outro ponto fundamental alcançado pelas novas regras foi a questão do registro e do licenciamento das empresas. Muitas vezes, as empresas tinham dificuldades enormes em legalizar suas atividades e eram obrigadas 
a pagar diversos tributos antes mesmo de começarem a funcionar e a gerar receita. A LG tornou muito mais simples e menos dispendioso para as MPE colocarem suas atividades em funcionamento. As novas regras, inclusive, podem beneficiar outros contribuintes, não incluídos no conceito de $\mathrm{ME}$ ou EPP, à medida que os entes federativos forem adotando normas simplificadoras, como já aconteceu no Município do Rio de Janeiro.

Uma importantíssima mudança, que aos poucos vai se difundindo nas administrações tributárias dos diferentes entes, é a substituição de mecanismos presenciais de registro e controle dos contribuintes por sistemas "online". Cada vez mais, a Internet será usada para cadastramento, licenciamento e controle fiscal das atividades econômicas, bem como para esclarecimento de dúvidas dos contribuintes.

Tais mudanças vêm trazendo enorme ganho de eficiência e redução de custos, tanto para o Fisco como para os contribuintes, dispensando o recurso a intermediários e diversos trâmites burocráticos. Por exemplo, no MRJ, até alguns anos atrás, era necessário comparecer pelo menos cinco vezes à repartição competente, a fỉm de obter o Alvará de Licença para Estabelecimento, e o procedimento correspondente levava em média quinze dias, isso quando não havia nenhuma pendência. Hoje em dia, na maioria dos casos, é necessário comparecer apenas uma vez à repartição, e todo o procedimento de licenciamento, no que toca às exigências municipais, pode ser finalizado em até três dias.

A simplificação tributária e administrativa, como se pode concluir, não traz benefícios apenas para as MPE ou para as empresas de um modo geral, mas para a economia nacional como um todo, pois esta se torna mais eficiente na geração de riquezas. As normas introduzidas pelo Estatuto e por legislações de teor semelhante trazem pouco ou nenhum custo para a Administração Pública, pois a renúncia de receita, quando chega a ocorrer, é plenamente compensada pelo ganho de eficiência e redução de gastos da máquina pública. Já o ganho para a economia é expressivo, pois as normas 
simplificadoras permitem que os agentes econômicos iniciem suas atividades com maior rapidez e voltem menos recursos e esforços para o cálculo dos tributos a pagar e para o simples cumprimento de obrigações tributárias acessórias ou outras de caráter administrativo.

Concluindo, podemos dizer que a simplificação é uma tendência irreversível na Administração Pública brasileira, não apenas no que se refere aos tributos, mas à própria atividade administrativa como um todo. Aos poucos, o Fisco deixa de assumir o papel de oponente, para se tornar parceiro dos agentes econômicos privados na busca da prosperidade. 


\section{Bibliografia}

CAMPINHO, Sergio. O Direito de Empresa à Luz do Novo Código Civil. $7^{\mathrm{a}}$ ed. Rio de Janeiro: Renovar, 2006. 373 p.

FABRETTI, Láudio Camargo. Simples Nacional. $1^{\mathrm{a}}$ ed. São Paulo: Atlas, 2007. $276 \mathrm{p}$.

MARTINS, Sergio Pinto. Manual do Imposto sobre Serviços. 5a ed. São Paulo: Atlas, 2003. 278 p.

MORAES, Alexandre de. Direito Constitucional. $17^{\mathrm{a}}$ ed. São Paulo: Atlas, 2005. $918 \mathrm{p}$.

PILATTI, Adriano. A Constituinte de 1987-1988: Progressistas, Conservadores, Ordem Econômica e Regras do Jogo. $1^{\text {a }}$ ed. Rio de Janeiro: Lumen Juris, 2008. 334 p.

REQUIÃO, Rubens. Curso de Direito Comercial: $1^{\mathrm{o}}$ volume. $26^{\mathrm{a}}$ ed. São Paulo: Saraiva, 2005. 538 p.

ROSA JR., Luiz Emygdio F. da. Manual de Direito Financeiro e Direito Tributário. $20^{\mathrm{a}}$ ed. Rio de Janeiro: Renovar, 2007. 942 p.

SILVA, José Afonso da. Curso de Direito Constitucional Positivo. $25^{\mathrm{a}}$ ed. São Paulo: Malheiros, 2005. 924 p. 